\title{
MPM Berbasis Konteks dan Strategi Pembelajaran Matematika Realistik Bagi Guru Matematika Tingkat SMP
}

\author{
Nasrullah $^{1}$, Wahidah Sanusi ${ }^{2}$, Muhammad Abdy ${ }^{3}$ \\ 1,2,3 Jurusan Matematika, Fakultas MIPA, Universitas Negeri Makassar
}

\begin{abstract}
Partners of the Community Partnership Program (PKM) are the Mathematics MGMP of Takalar Regency. The problems are 1) The teacher has not maximized active learning activities in the classroom 2) The teacher has not maximally utilized media and strategies in learning activities. For implementation, participants are involved in training activities whose implementation includes material presentation and practical activities. In presenting the material, participants are given materials on the concept of context-based learning media and realistic mathematics learning strategies. However, with the consideration of the Covid-19 pandemic so that the implementation of this training is carried out in virtual or other terms in the network (online). In the practical activity section, participants carry out practical activities for the preparation and development of learning contexts and learning scenarios with Realistic Mathematics learning strategies. To support the implementation of the activity, participants were given the opportunity to express their opinions with this activity, context-based manipulative learning media, and the Realistic Mathematical Approach (PMR). The result is $16.7 \%$ who know somewhat, meaning that they have read but have not implemented it in the learning class. The same thing happened for $33.3 \%$ where the participants knew enough, in other words, they understood PMR well but were not able to keep pace with its development. The remaining 50\% have carried out this learning in their respective classes.
\end{abstract}

Keywords: Manipulative Learning Media, Context, Realistic Mathematics Learning

\section{PENDAHULUAN}

Pentingnya strategi pembelajaran untuk diterapkan dalam kegiatan pembelajaran merupakan salah satu alternatif usaha untuk mencapai keberhasilan dalam pembelajaran (Alimuddin, Ruslan, \& Nasrullah, 2019; Nasrullah \& Baharman, 2018). Tidak terkecuali dalam pembelajaran matematika dimana perencanaan pembelajaraan yang baik dengan melibatkan model, pendekatan, atau metode yang dipadu dengan media pembelajaran interaktif akan memberikan kemudahan untuk mempelajari matematika siswa.

Dengan begitu, salah satu yang perlu guru perhatikan adalah mengoptimalkan media dan sumber belajar yang dimiliki (Nasrullah \& Baharman, 2017; Nasrullah, 2016. Dalam proses pembelajaran, buku teks utama yang digunakan peserta didik adalah merupakan sumber belajar yang terkadang tidak cukup mendukung kegiatan pembelajaran siswa. Agar pembelajaran matematika lebih mudah dicerna oleh siswa, guru diharapkan memanfaatkan media pembelajaran yang dimiliki secara optimal. Media pembelajaran manipulatif berbasis konteks memiliki banyak fasilitas yang dapat digunakan sebagai media pembelajaran yang memudahkan peserta didik dalam belajar dan guru dalam melaksanakan pembelajaran (Nasrullah, Asdar, Jeranah, 2020).

Media adalah sebuah alat yang mempunyai fungsi menyampaikan pesan (Bovee, 1997). Media pembelajaran adalah sebuah alat yang berfungsi untuk menyampaikan pesan pembelajaran. Pembelajaran adalah sebuah proses komunikasi antara pembelajar, pengajar dan bahan ajar. Komunikasi tidak akan berjalan tanpa bantuan sarana penyampai pesan atau media.

Bentuk-bentuk stimulus bisa dikembangkan melalui media pembelajaran diantaranya adalah hubungan atau interaksi manusia; realita; gambar bergerak atau tidak; tulisan dan suara yang direkam (Nasrullah, N., Upu, H. and Syahrullah, S., 2018; Usman Mulbar, Purnamawati \& Nasrullah, 2017). Kelima bentuk stimulus ini akan membantu pembelajar mempelajari bahasa asing. Namun 
demikian tidaklah mudah mendapatkan kelima bentuk itu dalam satu waktu atau tempat.

Selain itu, terkadang dalam kegiatan pembelajaran para pendidik, fasilitator atau instruktur memerlukan dukungan psikologis dari peserta didik untuk mengikuti berbagai aktivitas pembelajaran yang dilaksanakan. Akan tetapi, masalah yang muncul selanjutnya adalah persoalan minat, motivasi, disposisi matematis, daya tarik, dan lain sebagainya, menjadi tantangan bagi para pengajar untuk menstabilkan terlebih dahulu sebelum jauh terlibat seluruh para peserta didik. Dengan adanya media pembelajaran, peran ini dapat diinterpretasi melalui berbagai aktivitas harus meningkatkan motivasi pembelajar (Pemu, Nasrullah; Rahman, Amirullah. 2018). Penggunaan media mempunyai tujuan memberikan motivasi kepada pembelajar. Selain itu media juga harus merangsang pembelajar mengingat apa yang sudah dipelajari selain memberikan rangsangan belajar baru. Media yang baik juga akan mengaktifkan pembelajar dalam memberikan tanggapan, umpan balik dan juga mendorong mahasiswa untuk melakukan praktek-praktek dengan benar.

Ada beberapa kriteria untuk menilai keefektifan sebuah media. Hubbard mengusulkan sembilan kriteria untuk menilainya (Hubbard, 1983). Kriteria pertamanya adalah biaya. Biaya memang harus dinilai dengan hasil yang akan dicapai dengan penggunaan media itu. Kriteria lainnya adalah ketersedian fasilitas pendukung seperti listrik, kecocokan dengan ukuran kelas, keringkasan, kemampuan untuk dirubah, waktu dan tenaga penyiapan, pengaruh yang ditimbulkan, kerumitan dan yang terakhir adalah kegunaan. Semakin banyak tujuan pembelajaran yang bisa dibantu dengan sebuah media semakin baiklah media itu (Nasrullah, 2016; Nasrullah, 2015; Nasrullah, N., 2014).

Kriteria di atas lebih diperuntukkan bagi media konvensional. Thorn mengajukan enam kriteria untuk menilai multimedia interaktif (Thorn, 1995). Kriteria penilaian yang pertama adalah kemudahan navigasi. Sebuah program harus dirancang sesederhana mungkin sehingga pembelajar bahasa tidak perlu belajar komputer lebih dahulu. Kriteria yang kedua adalah kandungan kognisi, kriteria yang lainnya adalah pengetahuan dan presentasi informasi. Kedua kriteria ini adalah untuk menilai isi dari program itu sendiri, apakah program telah memenuhi kebutuhan pembelajaran si pembelajar atau belum. Kriteria keempat adalah integrasi media di mana media harus mengintegrasikan aspek dan ketrampilan bahasa yang harus dipelajari. Untuk menarik minat pembelajar program harus mempunyai tampilan yang artistik maka estetika juga merupakan sebuah kriteria. Kriteria penilaian yang terakhir adalah fungsi secara keseluruhan. Program yang dikembangkan harus memberikan pembelajaran yang diinginkan oleh pembelajar. Sehingga pada waktu seorang selesai menjalankan sebuah program dia akan merasa telah belajar sesuatu.

Dalam kesempatan ini, media pembelajaran berbasis konteks terpadu pendekatan matematika realistik diterapkan untuk mengimplementasikan penerapan matematika sebagai aktivitas manusia kepada pengajar matematika di sekolah. Selain itu, dengan mengembangkan pembelajaran matematika realistik yang kontekstual diharapkan keterlibatan peserta didik dapat meningkat dan berdampak pula pada pemahaman konsep pembelajaran matematika.

Adapun permasalahan mitra yang dihadapi adalah 1) Guru belum memaksimalkan kegiatan pembelajaran aktif di kelas, salah satunya matematika. 2) Guru belum maksimal memanfaatkan media dan strategi dalam kegiatan pembelajaran.

\section{METODE YANG DIGUNAKAN}

Solusi yang ditawarkan dalam rangka pemecahan masalah di atas dibagi menjadi dua bagian yaitu meliputi sajian materi dan kegiatan praktek. Dalam penyajian materi peserta diberikan materi-materi mengenai konsep media pembelajaran berbasis konteks dan strategi pembelajaran matematika realistik. Namun, dengan pertimbangan pandemi covid-19 sehingga pelaksanaan pelatihan ini dilakukan secara virtual atau istilah lainnya dalam jaringan (daring). 
Pada bagian kegiatan praktikum peserta melakukan kegiatan praktek penyusunan dan pengembangan konteks pembelajaran dan skenario pembelajaran dengan strategi pembelajaran Matematika Realistik. Pada awal pelatihan peserta akan melakukan kerja mandiri setelah pemberian materi dilakukan. Setelah itu, peserta melakukan presentasi dan diskusi tentang apa yang telah dikembangkan dalam praktikum pembuatan konteks tersebut.

\section{PELAKSANAAN DAN HASIL KEGIATAN}

\section{A. Pelatihan secara daring}

Pada tahapan ini, tim pengabdi menyampaikan tujuan kegiatan dan materi yang diberikan dalam pelatihan ini melalui platform zoom meeting. Sebelumnya, seluruh peserta dijaring melalui media sosial whatsapp dan melengkapi seluruh informasi yang dibutuhkan menggunakan perangkat lunak online google form. Di tengah keterbatasan ini, kegiatan dapat berjalan dengan baik meskipun pertemuan tidak dilakukan secara langsung. Adapun situasi dalam kegiatan tersebut ditunjukkan seperti gambar di bawah ini.

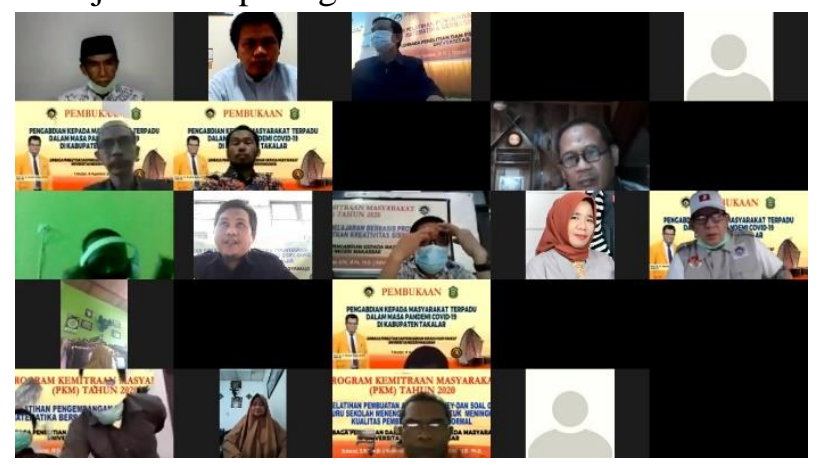

Gambar 1. Memperkenalkan asesoris dan penempatannya

\section{B. Penyajian Materi}

Pada tahapan ini tim pengabdi mengawali kegiatan dengan menyampaikan materi kegiatan. Ini dilakukan untuk memberikan penjelasan tentang media pembelajaran berbasis konteks dan strategi pembelajaran matematika realistik bagi guru matematika tingkat SMP.

Gambar ini merupakan bagian awal dari materi yang diberikan dalam pelatihan tersebut.

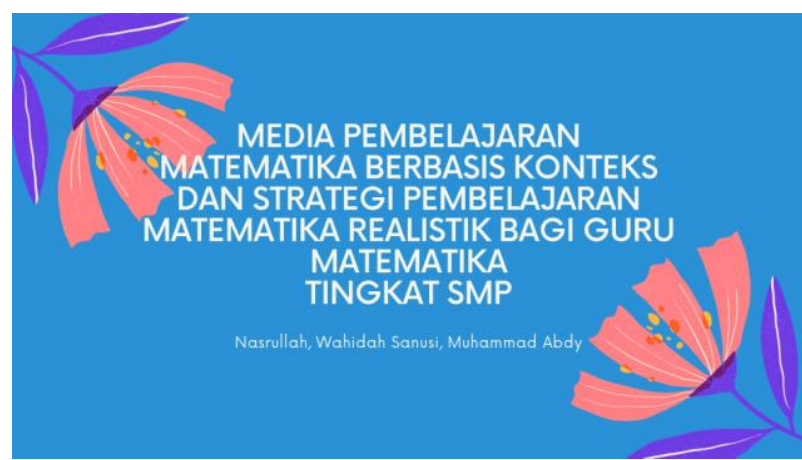

Gambar 2. Memperlihatkan desain asesoris dan memasang asesoris

\section{Melatih dan Mendampingi Mitra Memahami Media Pembelajaran Berbasis Konteks}

Pada tahapan ini, tim pengabdi melatih dan mendampingi mitra untuk mempraktikan penggunaan konteks dipadu dengan pendekatan matematika realistik secara online.

Untuk kegiatan ini, perangkat yang digunakan adalah google form dimana berbagai kegiatan dibuat ke dalam perangkat google form tersebut seperti diantaranya media pembelajaran berbasis konteks, lembar reposn PKM Konteks dan RME, dan penggunaan strategi pembelajaran matematika realistik terhadap konteks.

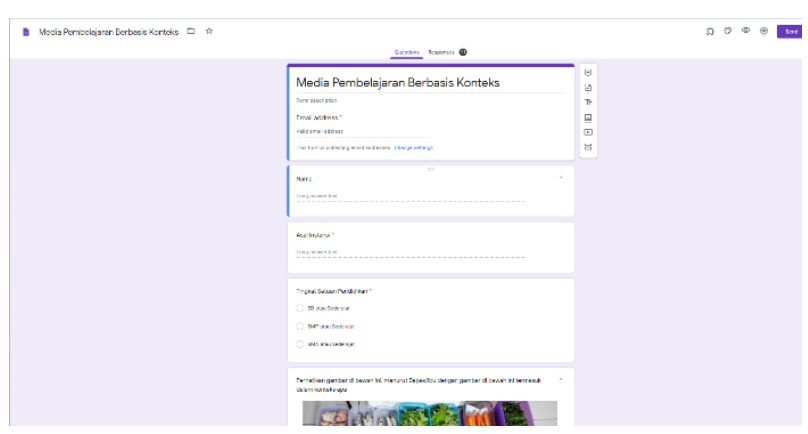

Gambar 3. Media Pembelajaran Berbasis Konteks

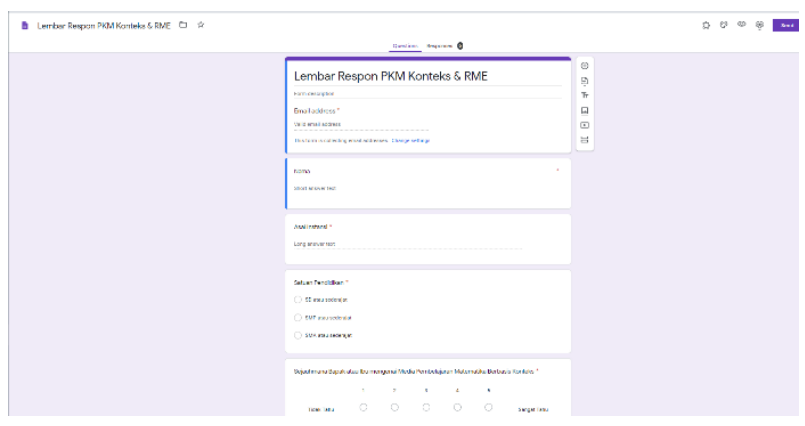

Gambar 4. Lembar Respon PKM Konteks dan RME 


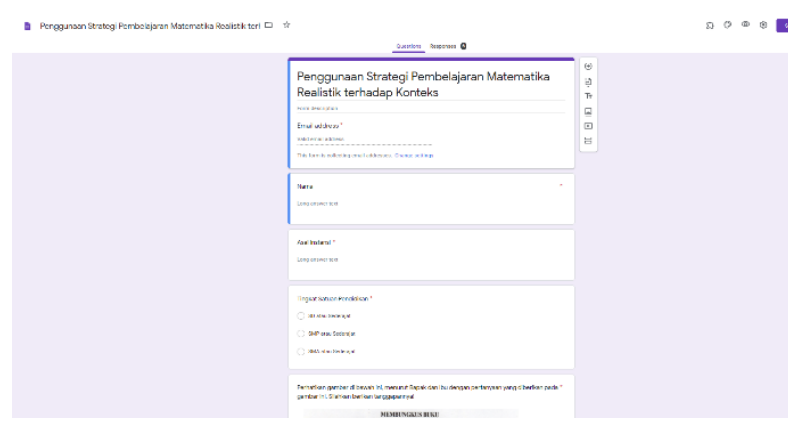

Gambar 5. Penggunaan Strategi Pembelajaran Matematika Realistik terhadap Konteks

\section{Respon Peserta Pelatihan}

Di dalam kegiatan, para peserta pelatihan diberikan angket dengan butir pernyataan seperti gambar di bawah ini.

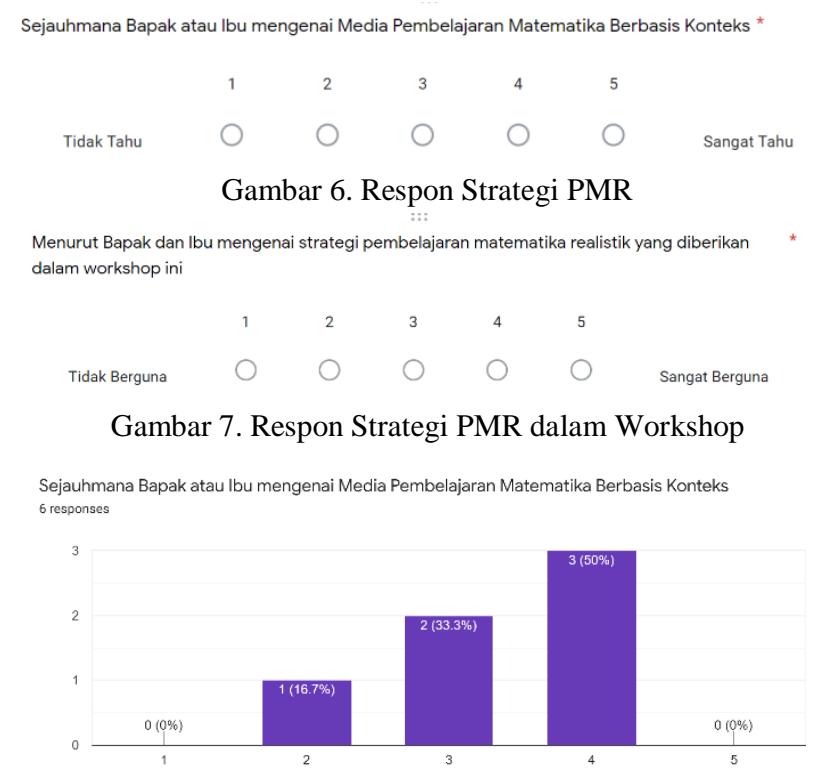

Gambar 8. Tanggapan Peserta dengan Strategi PMR

Untuk gambar 7 indikator repson dimulai dari tidak tahu sampai sangat tahu, atau dengan angka dari 1 sampai dengan 5. Berdasarkan gambar di atas menunjukkan $16,7 \%$ yang agak tahu, artinya pernah membaca tapi belum menerapkan di kelas pembelajaran. Hal serupa terjadi untuk 33,3\% dimana peserta cukup tahu, dengan kata lain memahami dengan baik PMR, tapi belum dapat sejalan dengan pengembangannya. Sisanya sebesar $50 \%$ telah menjalankan pembelajaran ini di kelas mereka masing-masing.

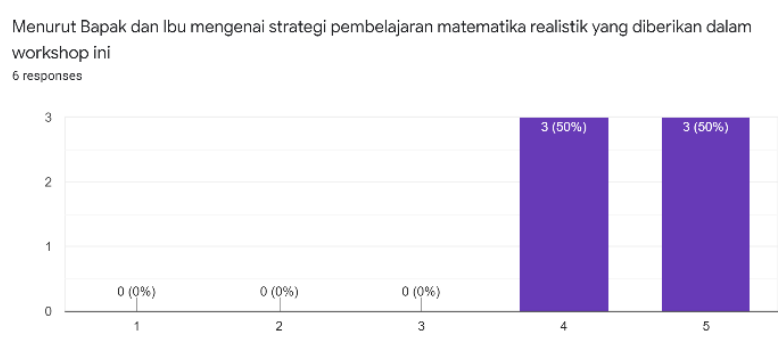

Gambar 9. Tanggapan Peserta dengan Strategi PMR dalam Workshop

Untuk gambar 8 indikator respon dimulai dari tidak berguna sampai sangat berguna. Berdasarkan gambar di atas menunjukkan respon peserta dengan kegiatan ini seluruhnya menganggapnya berguna atau baik dilaksanakan di kelas pembelajaran, khususnya pembelajaran matematika.

\section{KESIMPULAN}

Dengan pelaksanaan kegiatan pelatihan kepada guru tentang penerapan media pembelajaran manipulatif berbasis konteks untuk pembelajaran matematika dapat diajukan beberapa kesimpulan sebagai berikut.

1. Kegiatan pelatihan memberikan tambahan pengetahuan yang berfungsi meningkatkan pengetahuan guru tentang media pembelajaran alternatif untuk pembelajaran matematika.

2. Keterampilan guru dalam mengembangkan kegiatan pembelajaran dengan memanfaatkan konteks dan pembelajaran

3. matematika realistik melengkapi pengetahuan dan pengalaman belajar melalui kegiatan pelatihan tersebut.

4. Penggunaan Media Pembelajaran Manipulatif Berbasis Konteks dapat mendukung dan menggiatkan inovasi pembelajaran yang melibatkan ilmu pengetahuan dan teknologi dalam pembentukan keterampilan guru di sekolah.

\section{UCAPAN TERIMA KASIH}

Ucapan terima kasih disampaikan kepada Fakultas MIPA UNM yang telah memberikan hibah dan LP2M UNM yang telah memfasilitasi pelaksanaan kegiatan Program Kemitraan Masyarakat, serta pihak PGRI Kabupaten Takalar 
yang telah menjadi mitra kerjasama dalam pelaksanaan program ini.

\section{DAFTAR PUSTAKA}

Alimuddin, Ruslan, Nasrullah. 2019. Do Scientific Learning and Problem-solving Develop Mathematics Students' Creativity? Proceedings of the 1st International Conference on Advanced Multidisciplinary Research (ICAMR 2018), ISBN: 978-94-6252-706-5, DOI: https://doi.org/icamr-18.2019.3

Bovee. Courland. (1997). Business Communication Today. Prentice Hall : New. York. Hofstetter, Fred T. (2001). Multimedia Literacy. Third Edition. McGraw-Hill.

Hubbard, P. 1983. Albanian Reflexives: Violations of Proposed Universals. Kansas Working Papers in Linguistics, 8.1.

Nasrullah, N. and Baharman, B., 2017, October. Pengaruh SMP Virtual terhadap Kemampuan Penalaran dan Komunikasi Siswa dalam Pembelajaran Matematika. In Prosiding Seminar Nasional Lembaga Penelitian UNM (Vol. 2, No. 1).

Nasrullah, N., Upu, H. and Syahrullah, S., 2018. Model Pembelajaran STTP bagi Mahasiswa dalam Penyusunan Modul Pembelajaran Matematika Berbasis eXeLearning. Jurnal MATEMATIKA DAN PEMBELAJARAN, 5(2), pp.112-120.

Nasrullah and Baharman, 2018. Exploring Practical Responses of M3LC for Learning Literacy. $J$. Phys.: Conf. Ser. 954 012007. DOI: https://doi.org/10.1088/17426596/954/1/012007

Nasrullah, Asdar, Jeranah, 2020. Using GeoMaSchool To Link Between Creativity and Performance for Students In Higher Education. Proceedings of the 7th Mathematics, Science, and Computer Science Education International Seminar, MSCEIS 2019, 12 October 2019, Bandung, West Java, Indonesia. http://dx.doi.org/10.4108/eai.12-10-

2019.2296536

Nasrullah, 2016. Using Daily Problems to Measure Math Literacy and Characterize Mathematical
Abilities for Students in South Sulawesi. Proceeding of International Coneference on Mathematics, Statistics, Computer Sciences, and Mathematics Education (ICMSCSME) 2015. ISBN: 978-602-72198-2-3

Nasrullah, 2015. Teachers' Creativity in Posing Problems of Mathematics using Traditional Games as Learning Context. Proceeding of International Conference on Education and Technology. Optimizing The Role of Character Education Through Science and Technology Towards Excellent and Intelligent Generation, ISBN: 978-607-9075-05-2. Published by Makassar State University, 20 August 2015.

Nasrullah, N., 2014. Kontribusi Model Pembelajaran Berbasis Proyek terhadap Faktor AIK dalam Pembelajaran Matematika Siswa Kelas II/3 SMPN 2 Makassar. Kreano, Jurnal Matematika Kreatif-Inovatif, 5(1), pp.48-55.

Pemu, Nasrullah; Rahman, Amirullah. 2018. Penggunaan Tarser Dalam Menyelesaikan Soal Operasi Penjumlahan Dan Pengurangan Pada Bilangan Bulat Tingkat SMP. Kreano, Jurnal Matematika Kreatif-Inovatif, [S.1.], v. 9, n. 2, p. 114-119, nov. 2018. ISSN 2442-4218. Available at: <https://journal.unnes.ac.id/nju/index.php/krean o/article/view/13351>. Date accessed: 29 may 2019.

doi:https://doi.org/10.15294/kreano.v9i2.13351.

JF Witte, TD Sterr, CA Thorn. 199, 1995. Knowledge management for educational information systems. CA Thorn. education policy analysis archives 9, 47, 2001.

Usman Mulbar, Purnamawati \& Nasrullah, 2017. Students' Mathematical Connection Based on Levels of Mathematical Abilities: Qualitative Study in SLETV. Proceeding $2^{\text {nd }}$ International Conference on Education, Science, and Technology (ICEST 2017), ISSN: 2352-5398, ISBN: 978-94-6252-403-3, https://doi.org/icest17.2017.57. Publisher Atlantis Press. 